Vol. 11 (1): 187-196 (2021)

\title{
AN ANALYSIS OF LOGISTICS VILLAGES IN TURKEY: KONYA SAMPLE
}

\author{
Hesham ALRAGHEB ${ }^{1}$, Hatice Canan GÜNGÖR ${ }^{2 *}$ \\ ${ }^{I}$ Necmettin Erbakan University, Faculty of Engineering, Department of Civil Engineering Konya, Turkey; \\ ${ }^{2 *}$ Necmettin Erbakan University, Seydisehir Vocational School, Department of Civil Defense and Firefighting, \\ Konya, Turkey; \\ *Corresponding Author Hatice Canan GÜNGÖR, e-mail: cgungor@erbakan.edu.tr;
}

Received December 2020; Accepted January 2021; Published February 2021;

DOI: https://doi.org/10.31407/ijees11.125

\begin{abstract}
Logistic center is a region where is operating national and international shipping, logistics and distribution activities from different operators. Logistic centers are becoming important hubs because of some criteria such as location according to transport network, the roles in regional development, economic developments in immediate surroundings. In this study, the current position of Kayacık, Konya examined with GIS analysis. As a result of criterias analysis, Konya has highway, railway, airway and being located transit point in terms of energy within the framework of east-west main axis. The study talked about how GIS works and his role to select the best decisions principally the suitable location of logistics village.
\end{abstract}

Keywords: Geographic Information Systems (GIS), Logistics Villages. 